\title{
Changes in Plasma IL-6, IL-10, TNF- $\alpha$ and Haematocrit in the Traditional Treatment of Anaemia in HBsAg Seropositive Patients with Raw Liquid Content of Malabar Spinach (Basella alba)
}

\author{
Mathew Folaranmi Olaniyann ${ }^{1, *}$, Tolulope Busayo Ojediran ${ }^{1}$, Shedrack Gbenga Olayinka²
}

\section{Mathew Folaranmi Olaniyan ${ }^{1, *}$, Tolulope Busayo Ojediran', Shedrack Gbenga Olayinka ${ }^{2}$}

\section{'Department of Medical Laboratory Sci- ence, Edo University, lyamho, NIGERIA. ${ }^{2}$ Department of Medical Laboratory Science, Achievers University Owo, NIGERIA. \\ Correspondence \\ Mathew Folaranmi Olaniyan Department of Medical Laboratory Sci- ence, Edo University, lyamho, NIGERIA. \\ Phone: 2348052248019 \\ Email: olaniyanmat@yahoo.com \\ History \\ - Submission Date: 13-05-2019 \\ - Review completed: 29-06-2019; \\ - Accepted Date: 18-07-2019.}

\section{DOI : 10.5530/ijcep.2019.6.2.16}

\section{Copyright}

(c) 2019 Phcog.Net. This is an openaccess article distributed under the terms of the Creative Commons Attribution 4.0 International license.

\begin{abstract}
Background and Aim: Amunututu- Malabar Spinach (Basella alba) is one of the vegetable plants used in the traditional treatment of anemia in Saki-West Local Government Area of Nigeria due to its haematopoetic phytochemical and phytonutrient constituents. Hepatitis B surface antigen in the plasma is an indication of inflammation of the liver caused by Hepatitis $B$ virus infection. This work was designed to determine possible anti-anaemic and antiinflammatory nutritional values of raw liquid content of Basella alba. Methods: Thirty-seven (37; Female-16; Male-21; aged 14- 76 years) anaemic patients receiving treatments in eleven herbal homes in Saki-West Local Government area - Nigeria with a haematocrit of $19.0 \pm$ $2.0 \%$ were initially recruited. Thirteen (13; Female - 3; Male- 10) anaemic mono-infected HBsAg seropositive patients were studied. Twenty (20; Feale-9; Male-11) volunteers of the thirty-seven anaemic patients not infected with any of Plasmodium, HBV, HCV, HIV and M. tuberculosis were also studied. 50 (Female-25; Male-25) age matched volunteers who were neither anaemic nor infected with any of Plasmodium, HCV, HIV, HBV and M. tuberculosis were studied as control. Plasma IL-6, IL-10. TNF- $\alpha$, HBV, HCV and HIV were determined by ELISA technique while identification of $M$. tuberculosis and Plasmodium spp., was carried out by fluorescence and Geimsha-Thick film microscopy. Results: There was a significant increase in TNF- $\alpha$ and a significant decrease in Haematocrit, IL-6 and IL-10 in mono-infected $\mathrm{HBsAg}$ seropositive anaemic patients before the administration of raw liquid extract of $\mathrm{Ba}-$ sella alba compared with normal control subjects $(p<0.05)$. After the administration of raw liquid extract of Malabar Spinach there was a significant decrease in TNF- $\alpha$ and a significant increase in Haematocrit, IL-6 and IL-10 in these patients when compared with the value before the supplementation $(p<0.05)$. There was also a significant increase in the value of haematocrit in mono-infected HBsAg seropositive anaemic patients and anemic patient without infectious agents when values before supplementation was compared with the results obtained after the administration of raw liquid extract of Basella alba $(p<0.05)$. Conclusion: Basella alba has possible haemopoetic and anti-inflammatory bioactivities.

Key words: IL-6, IL-10, TNF- $\alpha$, Haematocrit, Anaemia, HBsAg seropositive patients, Malabar Spinach (Basella alba).
\end{abstract}

\section{INTRODUCTION}

Malabar Spinach (Basella alba) known as Amunututu in Yoruba language is rich in Vitamins A and C, iron, Vitamin-B6 (pyridoxine), potassium, manganese, magnesium and copper, riboflavin, folic acid and calcium. It contains $ß$-carotene, lutein, zea-xanthin, phenolic phytochemicals and has antioxidant

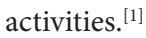

Anaemia is a clinical condition whereby the haemoglobin concentration is less than 130 to $140 \mathrm{~g} / \mathrm{L}$ (13 to $14 \mathrm{~g} / \mathrm{dL}$ ) in men and below 120 to $130 \mathrm{~g} / \mathrm{L}$ (12 to $13 \mathrm{~g} / \mathrm{dL}$ ) in women. Haematocrit (volume percentage (vol \%) of red blood cells in blood) is normally $47 \%+-5 \%$ for men and $42 \%+-5 \%$ for women. ${ }^{[2]}$ Anaemia is a clinical condition in which the number of red blood cells or their oxygen-carrying capacity is insufficient to meet physiologic needs, which vary by age, sex, altitude, smoking and pregnancy status. It is characterized by low haematocrit. ${ }^{[3]}$ There are three main causes and types of anemia. They include anaemia due to blood loss that could occur in ante and postpartum hemorrhage, trauma, gastrointestinal bleeding; decreased red blood cell production such as in vitamin B12 deficiency, thalasaemia, neoplasm of the bone marrow and increased red blood cell breakdown in sickle cell anaemia, infections and autoimmune diseases. ${ }^{[4]}$

Interleukin 10 (IL-10) is an anti-inflammatory cytokine that down regulates the $\mathrm{T}$ helper cells that
Cite this article: Olaniyan MF, Ojediran TB, Olayinka SG. Changes in Plasma IL-6, IL-10, TNF- $\alpha$ and Haematocrit in the Traditional Treatment of Anaemia in HBsAg Seropositive Patients with Raw Liquid Content of Malabar Spinach (Basella alba). Int J Clin Exp Physiol. 2019;6(2):61-5. 
stimulate B-cells for antibody production and activate cytotoxic T lymphocytes for the destruction of pathogens. It inhibits production of proinflammatory cytokines such as TNF- $\alpha .{ }^{[5]}$ TNF- $\alpha$ is an inflammatory cytokine involved in systemic inflammation and acute phase reaction. It is produced by $\mathrm{CD} 4+$ lymphocytes, NK cells, neutrophils, mast cells, eosinophils and neurons. ${ }^{\left[{ }^{[6]}\right.}$ TNF- $\alpha$ induces fever, apoptotic cell death, cachexia which involves loss of weight, muscle atrophy, fatigue, weakness and significant loss of appetite, inflammation and to inhibit tumorigenesis and viral replication. ${ }^{[7]}$ Interleukin 6 (IL-6) can function as both a pro-inflammatory cytokine and an anti-inflammatory myokine. IL-6 is a glycoprotein growth factor that regulates the proliferation and maturation of blood cell. ${ }^{[8]}$ Smooth muscle cells in blood vessels produce IL-6 as a pro-inflammatory cytokine. IL- 6 acts as anti-inflammatory cytokine by inhibiting the effects on TNF-alpha and IL-1. IL-6 also activates IL-1RA and IL-10 for anti-inflammatory activities. ${ }^{[9]}$

Symptoms of anaemia include weakness fatigue, poor concentration shortness of breath on exertion, palpitations, angina, intermittent claudication of the legs, heart failure and pallor. ${ }^{[10]}$ Hepatitis B surface antigen (HBsAg) seropositive patients are those individuals infected with Hepatitis $B$ virus. ${ }^{[10]}$ The virus upon infection stimulates immune response including inflammatory process and the release of hepatitis B surface antigen into the blood circulation. Hepatitis B surface antigen in the blood circulation is an indication of hepatitis $B$ as a result of presence of HBV in the hepatocytes. ${ }^{[1]}$

This work is therefore designed to determine changes in plasma IL-6, IL10 , TNF- $\alpha$ and blood haematocrit in the traditional treatment of anaemia in HBsAg seropositive patients using raw liquid content of Amunututu- Malabar Spinach (Basella alba) to be able to evaluate possible anti-anaemic and anti-inflammatory nutritional values of raw liquid content of Basella alba.

\section{MATERIALS AND METHODS}

\section{Study Area}

Eleven herbal homes in Saki-West local government area of Oyo StateNigeria. Saki West is a Local Government Area in Oyo State, Nigeria. Its headquarters are in the town of Saki. Saki, Nigeria is located at the extreme end of Oyo state. It has a Ressetlement center of 2nd Mechanised division of Nigerian Army, The Oke-Ogun Polytechnic, Baptist Medical Centre, Muslim Hospital, Baptist School of Nursing, School of Medical Laboratory Technology, Oyo State Hospital and a Technical college. Saki, Nigeria is also one of the largest cities in Oyo state. It shares border with Kwara state and Burkina Faso.

\section{Study Design and Study Population}

Thirty-seven anemic patients out of which 16 were females and 21 were males aged between 14 to 76 years, receiving traditional treatments in eleven herbal homes in Saki-West Local Government area - Nigeria with a Pack Cell Volume of $19.0 \pm 2.0 \%$ were initially recruited. Thirteen anemic HBsAg seropositive patients who were not co-infected with Plasmodium, HCV, HIV and M. tuberculosis were studied in which 3 were females and 10 were males. Twenty (20; Feale-9; Male- 11) volunteers of the thirty-seven anaemic patients recruited who were not infected with any of Plasmodium, HBV, HCV, HIV and M. tuberculosis were also studied. 50 (Female-25; Male-25) age matched volunteers who were neither anaemic nor infected with any of Plasmodium, HCV, HIV, HBV and $M$. tuberculosis were studied as control subjects. Plasma IL-6, IL-10. TNF- $\alpha$, HBV, HCV and HIV were determined by ELISA and immunobloting techniques while identification of M. tuberculosis and Plasmodium sp., was carried out by fluorescence and Geimsha-Thick film microscopy.

\section{Biological samples}

Five milliliter of venous blood samples was obtained from each subjects into Lithium heparinized anti-coagulated bottle to determine plasma IL-6, IL-10. TNF- $\alpha$, Plasmodium, HBV, HCV and HIV infections while sputum samples were obtained from each subject for identification of $M$. tuberculosis.

\section{METHODS}

\section{Preparation and Administration of raw liquid extract of Malabar Spinach (Basella alba) Amunututu in Yoruba language}

Fresh leaves were plucked and confirmed by Oyo State Agricultural Development Programme, Saki-Nigeria. The leaves were washed, drain and squeezed without adding any liquid substance. Seventy milliliters of the raw liquid extract was administered orally to the patients. This process was repeated 3 times in a day for 2 weeks by the herbal Practioners monitored by the researchers

\section{TNF-alpha ELISA}

Plasma TNF alpha was determined in the subjects using Abcam's ELISA kit. A monoclonal antibody specific TNF alpha has been coated onto the wells of the microtiter strips provided. Samples, including standards of known TNF alpha concentrations, control specimens or unknowns are pipetted into these wells. During the first incubation, the standards or samples and a biotinylated monoclonal antibody specific for TNF alpha are simultaneously incubated. After washing, the enzyme Streptavidin-HRP, that binds the biotinylated antibody is added, incubated and washed. A TMB substrate solution is added which acts on the bound enzyme to induce a colored reaction product. The intensity of this colored product is directly proportional to the concentration of TNF alpha present in the samples.

\section{IL-10 ELISA}

Plasma IL-10 was determined in the subjects using Abcam's kit. A monoclonal antibody specific for IL-10 has been coated onto the wells of the microtiter strips provided. Samples, including standards of known IL10 concentrations, control specimens or unknowns are pipetted into these wells. During the first incubation, the standards or samples and a biotinylated monoclonal antibody specific for IL-10 are simultaneously incubated. After washing, the enzyme Streptavidin-HRP, that binds the biotinylated antibody is added, incubated and washed. A TMB substrate solution is added which acts on the bound enzyme to induce a colored reaction product. The intensity of this colored product is directly proportional to the concentration of IL-10 present in the samples.

\section{IL-6 ELISA}

Plasma IL-6 was determined in the subjects using Abcam's kit. This entire complex (capture antibody/analyte/detector antibody) is in turn immobilized via immunoaffinity of an anti-tag antibody coating the well. To perform the assay, samples or standards are added to the wells, followed by the antibody mix. After incubation, the wells are washed to remove unbound material. TMB substrate is added and during incubation is catalyzed by HRP, generating blue coloration. This reaction is then stopped by addition of Stop Solution completing any color change from blue to yellow. Signal is generated proportionally to the amount of bound analyte and the intensity is measured at $450 \mathrm{~nm}$. Optionally, instead of the endpoint reading, development of TMB can be recorded kinetically at $600 \mathrm{~nm}$. 
Laboratory Identification of Plasmodium spp.Laboratory diagnosis of malaria was carried out by Microscopy using Geimsha-Thick film method as described by Cheesbrough, (2002). ${ }^{[12]}$

\section{Anti-HCV ELISA Assay}

This was assayed using Anti-Hepatitis C Virus Core Antigen antibody Abcam kit.

\section{HIV ELISA Test}

HIV test was carried out using Genscreen ${ }^{\text {Tn }}$ ULTRA HIV Ag-Ab Biorad Kit.

The Genscreen ${ }^{\mathrm{Tn}}$ ULTRA HIV Ag-Ab is an enzyme immunoassay based on the principle of the sandwich technique for the detection of HIV antigen and of the various antibodies associated with HIV-1 and/or HIV-2 virus in human serum or plasma.

\section{HBsAg ELISA Test}

This was assayed using Diagnostic automation/ Cortez Diagnostics, INC kit by ELISA method

Principle: The HBsAg ELISA Test kit employs an antibody sandwich ELISA technique where monoclonal antibodies unique to $\mathrm{HBsAg}$, are pre-coated on polystyrene microwells strips. The serum or plasma sample is added together with a second antibody, the horseradish peroxidase (HRP) conjugate and directed against a different epitope of HBsAg. Throughout the time of incubation, specific immunocomplex that may have formed (indicating presence of $\mathrm{HBsAg}$ ) is captured on the solid phase. After washing, to eliminate serum proteins and unbound HRP-conjugate, chromogen solutions containing Tetramethyl-benzidine (TMB) and urea peroxide are added to the wells. Next, the colorless chromogens are hydrolyzed by the bound HRP-conjugate to a blue-colored product while in the presence of the antibody-antigen-antibody (HRP) sandwich immunocomplex. Halting the reaction with sulfuric acid, the blue color then turns yellow. The color intensity is gauged proportionally to the amount of antigen captured in the wells and to the amount in the sample, respectively. The wells remain colorless if the HBsAg result is negative.

\section{Identification of Mycobacterium tuberculosis in sputum using fluorescence microscopy (auramine-rhodamine staining) Principle}

The specimen is illuminated with light of a specific wavelength (or wavelengths) which is absorbed by the fluorophores, causing them to emit light of longer wavelengths (i.e., of a different color than the absorbed light). The illumination light is separated from the much weaker emitted fluorescence through the use of a spectral emission filter. Typical components of a fluorescence microscope are a light source (xenon arc lamp or mercury-vapor lamp are common; more advanced forms are high-power LEDs and lasers), the excitation filter, the dichroic mir- ror (or dichroic beam splitter) and the emission filter. The filters and the dichroic beam splitter are chosen to match the spectral excitation and emission characteristics of the fluorophore used to label the specimen (Spring, 2008). ${ }^{[13]}$ In this manner, the distribution of a single fluorophore (color) is imaged at a time. Multi-color images of several types of fluorophores must be composed by combining several single-color images (Spring, 2008). ${ }^{[13]}$

Most fluorescence microscopes in use are epifluorescence microscopes, where excitation of the fluorophore and detection of the fluorescence are done through the same light path (i.e. through the objective). These microscopes are widely used in biology and are the basis for more advanced microscope designs, such as the confocal microscope and the total internal reflection fluorescence microscope.

\section{Ethical Considerations and Clearances}

This work was approved by ethical and research committee of Baptist Medical center Saki-Nigeria before the commencement of this work. Informed consent was also obtained from each of the patient and control subjects.

\section{Method of Statistical Analysis}

The results obtained were subjected to statistical analysis using SPSS 18.0 to determine mean, standard deviation, probability, student " $\mathrm{t}$ " test and level of significance was fixed below 0.05 .

\section{RESULTS}

There was a significant increase in TNF- $\alpha$ and a significant decrease in Haematocrit, IL-6 and IL-10 in mono-infected HBsAg seropositive anaemic patients before the administration of raw liquid extract of Amunututu- Malabar Spinach (Basella alba) compared with normal control subjects ( $p<0.05$; Table 1,2; Figure 1). There was a significant decrease in TNF- $\alpha$ and a significant increase in Haematocrit, IL-6 and IL-10 in mono-infected HBsAg seropositive Anaemic patients after the administration of raw liquid extract of Amunututu- Malabar Spinach (Basella alba) compared with the value before the supplementation $(p<0.05$; Table 1,2; Figure 1).

There was also a significant increase in the value of Haematocrit in mono-infected HBsAg seropositive anaemic patients and anemic patient who were not infected with the infectious agents (Plasmodium, HCV, HIV, HBV and M. tuberculosis) before and after treatment compared with the result obtained after the administration of raw liquid extract of Amunututu- Malabar Spinach (Basella alba) $(p<0.05$; Table 1-3; Figure $1)$.

However, there was no significant difference in the value of in TNF- $\alpha$, IL-10 and IL-6 in mono-infected HBsAg seropositive anaemic patients compared with anemic patient not infected with the infectious agents (Plasmodium, HCV, HIV, HBV and M. tuberculosis) and control after

Table 1: Mean and Standard deviation of plasma IL-6, IL-10, TNF- $a$ and Haematocrit obtained in the subjects.

\begin{tabular}{|c|c|c|c|c|c|}
\hline & Control $(n=50)$ & $\begin{array}{l}\text { Mono-infected Anaemic } \\
\text { HBsAg seropositive } \\
\text { patients }(n=13) \text { before } \\
\text { treatment }\end{array}$ & $\begin{array}{l}\text { Mono-infected Anaemic } \\
\text { HBsAg seropositive } \\
\text { patients ( } n=13) \text { after } \\
\text { treatment }\end{array}$ & $\begin{array}{l}\text { Anemic patient } \\
\text { without infectious agents } \\
(n=20) \text { before treatment }\end{array}$ & $\begin{array}{c}\text { Anemic patient } \\
\text { without infectious } \\
\text { agents }(n=20) \text { after } \\
\text { treatment }\end{array}$ \\
\hline Haematocrit (\%) & $40 \pm 5.0$ & $19.0 \pm 2.0$ & $28.0 \pm 2.0$ & $20.0 \pm 1.0$ & $29.0 \pm 2.0$ \\
\hline IL-6 (pg/ml) & $3.2 \pm 0.2$ & $2.0 \pm 0.1$ & $3.0 \pm 0.2$ & $3.1 \pm 0.1$ & $3.0 \pm 0.2$ \\
\hline IL-10 (pg/ml) & $4.5 \pm 0.2$ & $3.3 \pm 0.2$ & $4.0 \pm 0.1$ & $4.3 \pm 0.2$ & $4.4 \pm 0.1$ \\
\hline TNF- $\alpha(\mathrm{pg} / \mathrm{ml})$ & $2.5 \pm 0.3$ & $3.9 \pm 0.2$ & $2.8 \pm 0.1$ & $2.7 \pm 0.2$ & $2.6 \pm 0.1$ \\
\hline
\end{tabular}


Table 2: Comparative analysis of Mean and Standard deviation of plasma IL-6, IL-10, TNF- $\alpha$ and haematocrit obtained in mono-infected anaemic HBsAg seropositive patients and normal control.

\begin{tabular}{|c|c|c|c|c|}
\hline & & $\begin{array}{l}\text { Mono-infected Anaemic } \\
\text { HBsAg seropositive patients } \\
(n=13) \text { before treatment } \\
\text { Vs. } \\
\text { Control }\end{array}$ & $\begin{array}{l}\text { Mono-infected Anaemic } \\
\text { HBsAg seropositive patients } \\
(n=13) \text { after treatment } \\
\text { Vs. } \\
\text { Control }\end{array}$ & $\begin{array}{l}\text { Mono-infected Anaemic HBsAg seropositive patients } \\
\qquad \begin{array}{l}\text { (n=13) before treatment } \\
\text { Vs. }\end{array} \\
\text { Mono-infected Anaemic HBsAg seropositive patients } \\
\text { ( } n=13) \text { after treatment }\end{array}$ \\
\hline \multirow[t]{2}{*}{ Haematocrit (\%) } & $' t '$ & -3.8996 & -2.228 & -3.18198 \\
\hline & ' $p$ ' & $0.03^{*}$ & 0.0778 & $0.043^{*}$ \\
\hline \multirow[t]{2}{*}{ IL-10 (pg/ml) } & ' $t$ ' & -3.90434 & -2.04265 & -3.1305 \\
\hline & ' $p$ ' & $0.03^{*}$ & 0.089 & $0.04434^{*}$ \\
\hline \multirow[t]{2}{*}{ TNF- $\alpha(p g / m l)$} & $' t '$ & 3.8829. & 0.94868 & 4.91935. \\
\hline & ' $p$ ' & $0.030^{*}$ & 0.221457 & $0.02^{*}$ \\
\hline
\end{tabular}

${ }^{*}$ Significant

Table 3: Comparative analysis of Mean and Standard deviation of plasma IL-6, IL-10, TNF- $\alpha$ and haematocrit obtained in mono-infected anaemic HBsAg seropositive patients and Anemic patient without infectious agents.

\begin{tabular}{|c|c|c|c|c|}
\hline & & $\begin{array}{l}\text { Mono-infected HBsAg } \\
\text { seropositive Anaemic patients } \\
\text { before treatment ( } n=13)\end{array}$ & $\begin{array}{l}\text { Mono-infected HBsAg seropositive } \\
\text { Anaemic patients after treatment } \\
\qquad(n=13)\end{array}$ & $\begin{array}{l}\text { Anemic patient without infectious agents } \\
\qquad(n=20) \text { before treatment } \\
\text { Vs. }\end{array}$ \\
\hline & & $\begin{array}{c}\text { Vs. } \\
\text { Anemic patient without } \\
\text { infectious agents }(n=20) \text { before } \\
\text { treatment }\end{array}$ & $\begin{array}{l}\text { Vs. } \\
\text { Anemic patient without infectious } \\
\text { agents }(n=20) \text { after treatment }\end{array}$ & $\begin{array}{l}\text { Anemic patient without infectious agents } \\
\qquad(n=20) \text { after treatment }\end{array}$ \\
\hline \multirow{2}{*}{$\begin{array}{l}\text { Haematocrit } \\
(\%)\end{array}$} & $' t '$ & -0.45 & -0.35 & -4.02 \\
\hline & 'p' & 0.35 & 0.38 & $0.03^{*}$ \\
\hline \multirow[t]{2}{*}{ IL-6 (pg/ml) } & ' $t$ ' & -7.78 & 0.00 & 0.45 \\
\hline & 'p' & $0.008^{*}$ & 0.5 & 0.35 \\
\hline \multirow[t]{2}{*}{ IL-10 (pg/ml) } & ' $t$ ' & -3.54 & -2.82 & -0.45 \\
\hline & 'p' & $0.04^{*}$ & 0.05 & 0.35 \\
\hline \multirow[t]{2}{*}{ TNF- $\alpha(\mathrm{pg} / \mathrm{ml})$} & ' $t$ ' & 4.24 & 1.41 & 0.45 \\
\hline & 'p' & $0.03^{*}$ & 0.15 & 0.35 \\
\hline
\end{tabular}

${ }^{*}$ Significant

administration of raw liquid extract of Amunututu- Malabar Spinach (Basella alba) ( $p>0.05$; Table 1, 3; Figure 1).

\section{DISCUSSION}

There was a significant increase in TNF- $\alpha$ and a significant decrease in Haematocrit, IL-6 and IL-10 in mono-infected HBsAg seropositive anaemic patients before the administration of raw liquid extract of Basella alba when compared with normal control subjects. Significant increase in TNF- $\alpha$ and a significant decrease in IL- 6 and IL-10 is an indication of inflammation and acute phase response as infection of hepatitis B virus affects the liver causing inflammation. ${ }^{[14,15]}$ TNF- $\alpha$ is an inflammatory cytokine that stimulate acute phase response in the liver upon inflammation such as viral hepatitis. Its plasma level rises to induce to inhibit viral replication which induces cell death and fever. ${ }^{[16]}$ IL- 6 can act as both anti and inflammatory cytokine. It is produced by smooth muscles in blood vessels. It inhibits production of TNF- $\alpha$, stimulates acute phase protein synthesis and activates IL-10 for antibody production and for

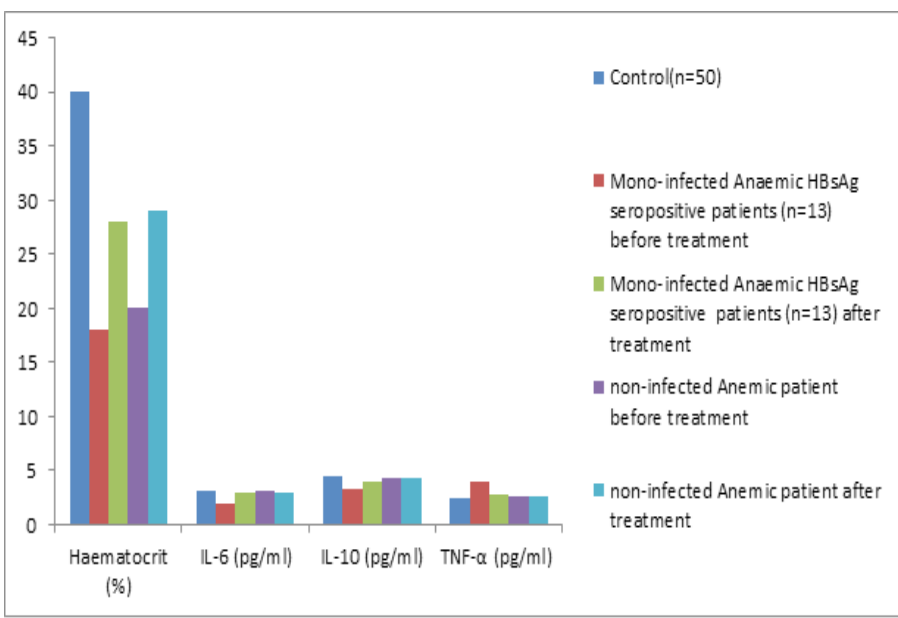

Figure 1: Comparative description of Mean and Standard deviation of plasma IL-6, IL-10, TNF-a and haematocrit obtained in the subjects. 
anti-inflammatory responses. Hence the decrease in plasma IL-6 and IL10 in hepatitis B virus infection is complicated by anaemia possibly due to loss of appetite or diminishes haemopoetic functions of the liver as liver is the main site of red blood cell production. ${ }^{[8,17-19]}$

There was a significant decrease in TNF- $\alpha$ and a significant increase in Haematocrit, IL-6 and IL-10 in mono-infected HBsAg seropositive anaemic patients after the administration of raw liquid extract of Malabar Spinach compared with the value before the supplementation. In mono-infected HBsAg seropositive anaemic patients and anemic patient without infectious agents before supplementation, there was also a significant increase in the value of haematocrit when compared with the results obtained after the administration of raw liquid extract of Basella alba.

Significant decrease in TNF- $\alpha$ and a significant increase in Haematocrit, IL- 6 and IL-10 could be attributed to the phytochemical and phytonutrient constituents of Malabar spinach as the vegetable leaves is very rich in Vitamin A, Vitamin C, iron, soluble fiber and calcium but low in calories. ${ }^{[1]}$ These findings can also be associated with the fact that Malabar spinach has antioxidant and anti-inflammatory bioactivities. ${ }^{[20]}$ In addition these findings could be linked with the fact that fresh leaves of Malabar spinach are rich in carotenoid pigment anti-oxidants which include $B$-carotene, lutein, zea-xanthin which act as protective scavengers against oxygen-from free radicals and Reactive Oxygen Species (ROS). These substances play a vital role in healing, aging and various disease processes. Furthermore, the vegetable is an excellent source of iron, Bcomplex vitamins like folate, vitamin-B6 (pyridoxine) and riboflavin required for red blood cell (RBC's) production. ${ }^{[1,20]}$

\section{CONCLUSION}

This work revealed anti-anaemic and anti-inflammatory nutritional values of raw liquid content of Basella alba and that anaemia may be a complication of Hepatitis B.

\section{ACKNOWLEDGEMENT}

I acknowledge the support of the patients and practitioners of the herbal homes to make this work a success.

\section{CONFLICT OF INTEREST}

The authors declare no conflict of interest.

\section{ABBREVIATIONS}

IL-6: Interleukin-6; IL-10: Interleukin-10; TNF-a: Tumor Necrosis Factor; HBsAg: Hepatitis B surface Antigen; HIV: Human Immunodeficiency Virus; HBV: Hepatitis B Virus; HCV: Hepatitis C Virus.

\section{REFERENCES}

1. Grubben GJH, Denton OA. Plant Resources of Tropical Africa 2. Vegetables. PROTA Foundation, Wageningen; Backhuys, Leiden; CTA, Wageningen. 2004.

2. Qaseem A, Humphrey LL, Fitterman N, Starkey M, Shekelle P. Treatment of anemia in patients with heart disease: A clinical practice guideline from the American College of Physicians. Annals of Internal Medicine. 2013;159(11):7709.

3. Janz TG, Johnson RL, Rubenstein SD. Anemia in the emergency department: Evaluation and treatment. Emergency Medicine Practice. 2013;15(11):1-15.

4. Mosser DM, Zhang X. Interleukin-10: New perspectives on an old cytokine. Immunological Reviews. 2008;226(1):205-18.

5. Swardfager W, Lanctôt K, Rothenburg L, Wong A, Cappell J, Herrmann N. A meta-analysis of cytokines in Alzheimer's disease. Biol Psychiatry. ;68(10):930-41.

6. Locksley RM, Killeen N, Lenardo MJ. The TNF and TNF receptor superfamilies: Integrating mammalian biology. Cell. 2010;104(4):487-501.

7. Broudy VC. Stem cell factor and hematopoiesis. Blood. 1997;90(4):1345-64.

8. Ferguson-Smith AC, Chen YF, Newman MS, May LT, Sehgal PB, Ruddle FH. Regional localization of the interferon-beta 2/B-cell stimulatory factor 2/hepatocyte stimulating factor gene to human chromosome 7p15-p21. Genomics. 1998;2(3):203-8

9. Einollahi B. Restless Leg Syndrome: A Neglected Diagnosis. Nephro-Urology Monthly. 2014;6(5):e22009.

10. Hunt R. Hepatitis viruses. University of Southern California, Department of Pathology and Microbiology. Retrieved. 2008-03-13.

11. Hassan MM, Li D, El-Deeb AS, Wolff RA, Bondy ML, Davila M, et al. Association between hepatitis B virus and pancreatic cancer. Journal of Clinical Oncology. 2008;26(28):4557-62.

12. Cheesebrough M. District laboratory practice in tropical countries. 2002; Part 1 Monica Cheesbrough, Eds.: Cambridge University Press,. Spring KR, Davidson MW. Introduction to Fluorescence Microscopy. Nikon MicroscopyU. 2008.

13. El-Serag HB, Rudolph KL. Hepatocellular carcinoma: Epidemiology and molecular carcinogenesis. Gastroenterology. 2007;132(7):2557-76.

14. El-Serag HB. Hepatocellular carcinoma. New England Journal of Medicine. 2011;365(12):1118-27.

15. Said EA, Dupuy FP, Trautmann L, Zhang Y, Shi Y, El-Far M, et al. Programmed death-1-induced interleukin-10 production by monocytes impairs CD4+ T cell activation during HIV infection. Nat Med. 2010;16(4):452-9.

16. Opp MR, Smith EM, Hughes TK. Interleukin-10 (cytokine synthesis inhibitory factor) acts in the central nervous system of rats to reduce sleep. Journal of Neuroimmunology. 1995;60(1-2):165-8.

17. Jelkmann $\mathrm{W}$. The role of the liver in the production of thrombopoietin compared with erythropoietin. European Journal of Gastroenterology and Hepatology. 2001;13(7):791-801.

18. Moore KW, DeWaal MR, Coffman RL, O'Garra A. Interleukin-10 and the interleukin-10 receptor. Annual Review of Immunology. 2001;19(1):683-765.

19. Swardfager W, Lanctôt K, Rothenburg L, Wong A, Cappell J, Herrmann N. A meta-analysis of cytokines in Alzheimer's disease. Biol Psychiatry. 2010;68(10):93041.

20. Lin SM, Lin BH, Hsieh WM, Ko HJ, Liu CD, Chen LG, et al. Structural identification and bioactivities of red-violet pigments present in Basella alba fruits. J Agric Food Chem. 2010;58(19):10364-72. 